\title{
Propaganda Politik Hoaks dalam Pemilihan Presiden Tahun 2019
}

\section{Hoaks Political Propaganda in the 2019 Presidential Election Rahman Tahir*, Heri Kusmanto \& Muryanto Amin}

\author{
Magister Ilmu Politik, Fakultas Ilmu-ilmu Sosial dan Ilmu Politik, Universitas Sumatera Utara, \\ Indonesia
}

Diterima: 01 Februari 2020; Disetujui: 08 April 2020; Diterbitkan: 01Juli 2020.

\begin{abstract}
Abstrak
Tujuan penelitian ini adalah untuk mengetahui dan menganalisis penggunaan propaganda hoaks, materi atau konten dan pola penggunaannya dalam pemilihan Presiden RI tahun 2019. Metode kualitatif digunakan dalam penelitian ini untuk mencari pengetahuan atau pemahaman berbagai relasi terkait dibalik suatu realitas pada era media baru, studi teks dan dokumentasi berita serta artikel tentang berita hoaks yang dapat mempengaruhi publik dan dapat menghambat serta mempengaruhi substansi demokrasi itu sendiri. Hasil penelitian menunjukkan bahwa tujuan propaganda politik hoaks selain mempengaruhi publik juga dilakukan untuk mengubah image negatif menjadi positif ataupun sebaliknya, agar meningkatkan elektabilitas dan kepopuleran calon yang didukung. materi atau konten yang digunakan sebagai propaganda hoaks adalah materi atau konten yang berisikan tentang SARA, personal, memakai pola penjulukan, transfer, iming-iming, narasi merakyat dengan menggunakan konten berita/informasiyang sifatnya negatif bahkan tidak jarang berisi kebohongan pola penggunaan propaganda hoaks yang digunakan dalam pemilihan presiden 2019. Pola penggunaan propaganda hoaks ini dihembuskan dalam media baru dengan cara berulang ulang (repetitive) dan berkesinambungan/kontiniutas untuk mengubah pikiran kognitif dan membangkitkan emosi masyarakat yang kurang memahami pendalaman terhadap politik.

Kata kunci: Propaganda, Politik, Hoaks, Pemilihan Presiden

\section{Abstract}

The purpose of this research is to find out and analyze the use of hoax propaganda, material or content and patterns of its use in the 2019 Presidential Election. Qualitative methods are used in this research to seek knowledge or understanding of various related relations behind a reality in the new media era, text studies and news documentation and articles about hoax news that can influence the public and can hinder and influence the substance of democracy itself. The results showed that the purpose of hoaks political propaganda in addition to influencing the public was also done to change the negative image into positive or vice versa, in order to increase the electability and popularity of the candidates supported. material or content that is used as propaganda hoaks is material or content that contains SARA, personal, uses a pattern of nicknames, transfers, lure, popular narrative by using news / information content which is negative in nature and even sometimes contains lies using hoax propaganda patterns that are used in the 2019 presidential election. The pattern of the use of hoax propaganda is exhaled in new media by repetitive and continuous ways to change cognitive thinking and arouse the emotions of people who do not understand the deepening of politics.

Keywords: Propaganda, Politics, Hoaks, Presidential Elections
\end{abstract}

How to Cite: Tahir, R. Kusmanto, H \& Amin, M. (2020). Propaganda Politik Hoaks dalam Pemilihan Presiden Tahun 2019. PERSPEKTIF, 9 (2): 236-251

*Corresponding author:

E-mail: athatahir@gmail.com ISSN 2085-0328 (Print) ISSN 2541-5913 (online) 


\section{PENDAHULUAN}

Fenomena post truth yaitu maraknya aktor gerakan dan tokoh populis dengan gencar berusaha menurunkan kepercayaan pada arus media dan pengetahuan ahli, sehingga tumbuh subur media alternatif sebagai entitas wacana tandingan, dengan menyampaikan opini publik dan propaganda dengan mendegradasi bahkan mengasampingkan fakta dan data yang objektif. (Harsin, 2015; Tallis, 2016). Post truth digunakan juga dalam propaganda dan mudah dilihat dalam kegiatan politik termasuk hoaks, kondisi tersebut berkaitan dengan keadaan fakta objektif kurang berpengaruh dalam membentuk opini masyarakat daripada menarik emosi dan kepercayaan (Feldman, 2017; Hendricks dan Vestergaard, 2019). Ketika memahami konsep post-truth penting sekali untuk mengeksplorasi perubahan dengan mempertimbangkan prasyarat psikologis, sosial, teknologi, dan konteksnya. Tendensi tren masyarakat ke ranah media baru telah berkontribusi pada gencarnya dunia post-truth selama beberapa dekade terakhir, adanya media baru menjadikan dunia tanpa batas.

Media baru menyebabkan adanya perubahan pada teknologi, tekstual konvensional dan kultural. Berikut adalah media baru yang paling sering digunakan sebagai media propaganda hoaks seperti twitter, facebook, laman/website. Media baru pada saat ini sangat dominan, dan tidak mengherankan bahwa pengaruh munculnya media baru membuat penyebaran propaganda hoaks semakin intensif (Bhaskaran, Mishra, dan Nair, 2017). Propaganda hoaks merupakan metode sekaligus alat yang sangat efektif untuk mendapatkan posisi politik sekaligus menjatuhkan posisi politik lawan yang dilakukan lebih dari satu kali atau secara terus menerus (repetitive action), serta berkesinambungan. Propaganda hoaks dinyatakan berhasil apabila dapat menjadi senjata yang ampuh untuk merendahkan musuh dan menghasut kebencian terhadap kelompok tertentu, mengendalikan keinginan propagandais bahwa pendapat itu yang benar meskipun hasil manipulasi.

Keberadaan teknologi dan media baru dibidang politik bukan tanpa problematika. Pilliang (1999) mengatakan perkembangan politik dalam media baru disebut sebagai $e$ - democracyyang telah membawa berbagai persoalan sosial yang mendasar di antaranya kekuasaan, kebenaran, hukum dan moralitas yang justru dalam perkembangannya menggiring masyarakat ke arah ruang yang anti demokrasi bahkan mencederai esensi demokrasi itu sendiri. Kebebasan berpendapat tak serta merta mendorong keaslian sebuah karya atau sumber. Merambahnya propaganda hoaks menjadi racun dan mereduksi demokrasi itu sendiri.

Menurut data Kantor Humas Kementrian Informatika sepanjang Agustus 2018 - April 2019 terdapat total 1.731 konten hoaks yang teridentifikasi adapun daftarnya kategori politik 620 hoaks, kategori pemerintahan 210 hoaks, kesehatan 200 hoaks, fitnah 159 hoaks kejahatan 113 hoaks dan isu isu lainnya. Dan selama April 2019 menjelang pemilihan terdapat sebanyak 486 konten yang teridentifikasi, 209 konten hoaks berasal dari kategori politik, selama 21 - 22 Mei 2019 kominfo menemukan 30 berita hoaks. Hoaks ini disebarkan sebanyak 1.932 URL ada 450 URL di Facebook, 518 instagram, 784 Twitter, 1 linkedIN. Hal ini teridentifikasi berdasarkan penelurusuran mesin Automatic Identification System (AIS) oleh Subdirektorat Pengendalian Konten Internet Direktorat Pengendalian Ditjen Aplikasi Informasika melalui portal kominfo.go.id dan stophoaks.id (detiknews.com 2019/05/01). Melalui pengamatan mereka juga sepanjang April tercatat 22 hoaks yang beredar di masyarakat. Dari 22 hoaks yang beredar, paling banyak terkait pemilihan presiden 2019.

Data dari Subdit II/Cyber Crime Direktorat Kriminal Khusus (Ditreskrimsus) Polda Sumut menangani 8 kasus ujaran kebencian dan Hoaks dalam kurun waktu Juni 2017 - Februari 2018. Dari 8 kasus ujaran kebencian tersebut hanya 2 (dua) kasus selesai hingga ke Jaksa Penuntut Umum (JPU) sedangkan 6 (enam) kasus masih dalam proses lidik (Sumut Pos 2018/07/05).

Sepanjang Mei 2019 di Kota Medan, menurut Kabid Humas Polda Sumatera Utara terdapat satu kasus yang ditangani oleh kepolisian menyebarkan video berita hoaks unjuk rasa people power yang telah mulai berlangsung di Kota Medan diamankan seorang pemuda inisial JP (30) warga Medan Labuhan (detiknews 19/05/2019). Peristiwa 
ini disebut sebagai propaganda hoaks dalam kegiatan politik.

Atas penjelasan di atas, penelitian ini menjelaskan asumsi terjadinya hoaks dalam pelaksanaan Pemilihan Presiden tahun 2019 di Kota Medan. Penelitian ini dilakukan untuk menganalisis dasar penggunaan hoaks dalam kegiatan politik yang berpotensi mempengaruhi opini pemilih.

Penelitian terdahulu menjadi salah satu acuan peneliti dalam melakukan penelitian sehingga peneliti dapat memperkaya teori yang digunakan dalam mengkaji penelitian yang dilakukan. Dari penelitian terdahulu, peneliti tidak menemukan penelitian dengan judul yang sama seperti judul penelitian peneliti. Namun peneliti mengangkat beberapa penelitian sebagai referensi dalam memperkaya bahan kajian pada penelitian peneliti.

Penelitian Allcott, $\mathrm{H}$ and Gentzkow, M. yang berjudul Social Media and Fake News in 2016 Election dalam Jurnal of Economic Perspectives- Vol 31, Number 2 - spring 2017 - pages 211 - 236 memaparkan bahwa pada tahun 2000-an, tumbuhnya berita online mendorong serangkaian kekhawatiran baru diantara mereka bahwa kelebihan sudut pandang akan memudahkan warga negara yang berpikiran sama untuk membentuk "ruang gema" dari "gelembung filter" dimana mereka akan diisolasi dari perspektif yang bertolak belakang (Sunstein 2001a, b, 2007; pariser 2011). Erond L. Damanik dalam artikelnya pada Iswandi Syahputra yang berjudul Demokrasi Virtual dan Perang Siber di Media Sosial: Perspektif Netizen Indonesia pada Jurnal ASPIKOM Volume 3 Nomor 3, Juli 2017 halaman 457-475) menemukan bahwa perang siber di media sosial telah membentuk dua polarisasi netizen. Polarisasi tersebut dapat diidentifikasi sebagai kelompok konservatif dan kelompok liberal, kedua kelompok tersebut aktif memproduksi wacana, opini, informasi, isu, dan rumor melalui media sosial. Penelitian ini memberikan implikasi pada perubahan atau pergeseran konsep pembuat opini pada teori two step communication, konsep pembuat opini dalam tradisi media baru yang muncul saat ini memungkinkan siapa saja secara anomin menjadi opinion leader. Juditha Christiany dalam penelitiannya yang berjudul Interaksi Komunikasi Hoaks di Media Sosial serta
Antisipasinya pada Jurnal Pekommas Volume 3 Nomor 1, April 2018: 31-44 memberikan gambaran tentang interaksi komunikasi hoaks di media sosial dan cara mengantisipasinya. Metode penelitian yang digunakan adalah pendekatan kualitatif dengan menyoroti tiga kasus hoaks yang ramai di masyarakat menyangkut pemerintahan Presiden Jokowi dan Gubernur DKI Jakarta dan Ahok. Hasil penelitian ini menyimpulkan bahwa interaksi komunikasi terbangun dengan sangat dimanis. Pengirim atau penerima pesan hoaks merupakan pihak yang tidak menyenangi pemerintah. Penerima pesan lainnya juga pihak yang tidak sepakat dan membantah hoaks sebagai dukungan terhadap pemerintah.

Fokus penelitian terdahulu ini banyak mengupas tentang hoaks, antisipasinya dan implikasi pergeseran opini publik sedangkan penelitian ini selain meneliti implikasi propaganda hoaks juga berfokus pada alasan aktor, materi atau konten yang selalu digunakan serta pola yang digunakan dalam menggunakan propaganda politik hoaks, dan implikasi yang diharapkan dapat merubah persepsi publik dalam penggiringan opini dan menghambat penyampaian informasi yang benar terhadap publik sehingga berdampak juga dalam delegitimasi demokrasi.

\section{METODE PENELITIAN}

Metode kualitatif digunakan dalam penelitian ini untuk mencari pengetahuan atau pemahaman berbagai relasi terkait dibalik suatu realitas pada era media baru, studi teks dan dokumentasi berita serta artikel tentang berita hoaks yang dapat mempengaruhi publik dan dapat menghambat serta mempengaruhi substansi demokrasi itu sendiri. Melalui studi teks dan dokumentasi berita serta artikel yang telah dibaca oleh peneliti secara berulang ulang sehingga peneliti dapat membuat sebuah analisis dan deskripsi. Menurut Bogdan dan Taylor, penelitian kualititatif adalah upaya yang dilakukan dengan jalan bekerja data, memilahnya menjadi satuan yang dapat dikelola, mensintesiskannya, mencari dan menemukan pola, menemukan apa yang penting dan apa yang dipelajari, dan memutuskan apa yang dapat diceritakan kepada orang lain. Berdasarkan definisi diatas dapat disimpulkan bahwa langkah awal dari analisis data adalah mengumpulkan data yang 
ada, menyusun secara lengkap, mengelola dan menganalisis (Moleong 2017).

Berdasarkan hasil penelitian data dikumpulkan melalui wawancara mendalam kepada narasumber penelitian, teknik studi observasi, dokumentasi dan studi literatur. Narasumber yang diwawancarai adalah aktivis media sosial yang bertidak sebagai opinion maker. Narasumber dipilih berdasarkan kelayakan dan ketersediaan akses peneliti terhadap narasumber dan kompetensi mereka (Stokes, 2006) bukan atas keterwakilan (representativeness) (Bernard, 1998). Sedangkan data dokumentasi yang dimaksud dalam penelitian ini adalah mencari, menemukan dan memeriksa kembali status di media sosial dan berita berita politik yang dapat mempengaruhi opini publik.

Penelitian ini menggunakan tiga teknik pengumpulan data; pertama, observasi yaitu mengamati konten isi berita mengenai propaganda hoaks yang terdapat di media sosial. Kedua, wawancara mendalam. Data juga dikumpulkan dan diuraikan melalui teknik wawancara mendalam (depth interview) dengan sejumlah informan. Ketiga, Focus Group Discussion (FGD) atau diskusi kelompok terarah terhadap pelaku, Diskusi kelompok yang dilakukan dengan para buzzer, pemilik media on-line di kota Medan serta pemerhati media sosial dan media konvensional. Peneliti menyediakan instrumen berupa pertanyaan tertulis dan dilakukan kepada buzzer, influencer media sosial, serta pemilik media on-line di kota Medan untuk membahas masalah propaganda hoaks.

Data yang diperoleh baik berupa dokumen tertulis, hasil wawancara dan hasil diskusi kelompok terarah dianalisa dengan menggunakan model analisis kualitatif. Bogdan dan Taylor mengemukakan bahwa metode analisa kualitatif sebagai prosedur penelitian menghasilkan data deskriptif berupa kata-kata tertulis maupun terucapkan dari pelaku yang diamati. Analisis kualitatif merupakan usaha mengambil kesimpulan berdasarkan pemikiran logis atas berbagai data yang diperoleh. Data dikumpulkan dan diseleksi, lalu disederhanakan dengan mengambil inti sarinya hingga ditemukan tema pokok, fokus masalah dan polanya.

Teknik analisa ini dilakukan dengan cara analisis isi (content analysis). Analisis isi (content analysis) digunakan untuk memperoleh keterangan dari komunikasi yang disampaikan dalam bentuk lambang yang terdokumentasi atau dapat didokumentasikan. Analisis isi dipakai untuk menganalisa semua bentuk komunikasi, seperti pada surat kabar, buku, media sosial, dan sebagainya. Dengan menggunakan metode analisis isi, maka akan diperoleh suatu pemahaman terhadap berbagai isi pesan komunikasi yang disampaikan oleh media massa atau dari sumber lain secara obyektif, sistematis, dan relevan (Subrayogo, 2001: 6).

\section{HASIL DAN PEMBAHASAN \\ Tujuan Penggunaan Hoaks sebagai Propaganda}

Propaganda sekarang merupakan bagian politik rutin yang normal dan dapat diterima sebagai komunikasi politik yang mempunyai tujuan untuk memengaruhi masyarakat dan dilakukan tidak hanya terbatas pada pesanpesan yang dibuat selama perayaan politik dan kampanye pemilihan eksekutif dan legislatif. Menurut Jacques Ellul sebagaimana dikutip Nimmo dalam buku Media Komunikasi Politik (Heryanto, 2018b) propaganda dapat dikatakan sebagai komunikasi yang dilakukan oleh suatu kelompok terorganisir yang ingin menciptakan pastisipasi aktif maupun pasif dalam tindakan suatu massa yang terdiri atas individu-individu, dipersatukan secara psikologis melalui manipulasi psikologis, dan digabungkan didalam suatu kelompok yang terorganisir.

Fenomena menggunakan media baru dalam propaganda politik merupakan hal yang baru dalam sejarah propaganda. Propaganda politik melalui media baru cukup efektif dibanding media konvensional karena pesan propaganda ada dibuat gambar dan narasi yang menarik perhatian pembaca, sehingga masyarakat tidak membutuhkan waktu yang lama untuk membaca atau mengartikan pesan yang disampaikan. Hoaks digunakan sebagai alat propaganda dan agitasi untuk menjatuhkan lawan politik. Pihak oposisi menggunakan hoaks sebagai alat propaganda dan agitasi karena belum punya unjuk kerja yang bisa dijadikan materi kampanye dalam Pilpres 2019.

Media baru memiliki kekuatan untuk membentuk opini publik yang akhirnya dapat mengangkat atau menjatuhkan citra seseorang. Asumsi tersebut sesuai dengan 
perspektif kerangka teori Berger dan Luckmann (1990) bahwa interaksi sosial dapat berlangsung melalui proses dialektika. Selanjutnya proses dialektika ini menciptakan tahapan, seperti subjective reality, symbolic reality, dan objective reality (Heryanto, 2018b). Objective reality merupakan realitias serta rutinitas tindakan dan tingkah laku yang telah terpola yang kesemuanya dihayati oleh individu secara umum sebagai fakta. Symbolic reality merupakan ekspresi simbolik dari apa yang dihayati sebagai objective reality. Selain itu, subjective reality merupakan konstruksi realitias yang dimiliki individu dan dikonstruksi melalui proses internalisasi. Tujuan penggunaan hoaks dalam pemilihan Pilpres tahun 2019 adalah mempengaruhi opini publik. Timbulnya opini publik meliputi dua sebab, yaitu direncanakan atau tidak direncanakan. Sebuah opini yang tidak direncanakan kemunculannya dikeluarkan karena memang tidak mempunyai tujuan dan target tertentu.

Pembuat opini ini direncanakan secara matang keorganisasian, media penyebar, target tertentu, sasaran akan menjadi jelas, tetap terus dipantau penyebarannya apakah narasi yang digulirkan tepat sasaran atau dimodifikasi sehingga menarik minat pembaca dan menjadi viral di ranah media baru.

Meskipun propaganda hoaks adalah tersistem dan memiliki sistem yang terorganisir, kadang hal ini tidak diketahui oleh yang sedang berkontestasi merebut kekuasaan; dalam hal ini pasangan calon Jokowi -Maaruf dan Pasangan calon PrabowoSandiaga dikarenakan banyak hal yang harus mereka lakukan dan selesaikan selain berkampanye ke seluruh pelosok Indonesia. Sehingga hal ini dapat saja dilakukan oleh pihak ketiga yang tidak berhubungan langsung dengan kontestan, yang tentunya mempunyai kepentingan besar atas kemenangan salah satu pasangan calon.

Opini publik sangat berperan didalam mempengaruhi sikap dan perilaku masyarakat. Sebuah opini dinyatakan benar manakala sudah tercapai suatu kesepakatan umum tentang kebenaran dari sebuah opini. Sedangkan untuk mencapai suatu kesepakatan tersebut membutuhkan sebuah proses atau tahapan-tahapan. Pendapat Tonnies bisa dijadikan analisis dalam masalah ini. Individu atau kelompok jelas mempunyai kepentingan tertentu. Untuk mewujudkan kepentingan tersebut, membutuhkan dukungan dari pihak lain. Dalam posisi ini, opini publik sengaja dimunculkan untuk mempengaruhi pendapat khalayak.

Tujuan melakukan propaganda hoaks selain mempengaruhi publik juga dilakukan untuk mengubah image negatif menjadi positif meningkatkan elektabilitas dan kepopularitasan atau sebaliknya untuk mengubah image positif menjadi negatif. Isu propaganda kian menyerang Jokowi dalam masa pemerintahannya dimulai dari Jokowi yang pro dengan PKI, Jokowi yang menerima tenaga kerja asing dengan mudah, hingga Jokowi yang takluk akan liberalism, sedangkan issue menyerang prabowo issue pelanngar HAM, dan dipecat dari TNI, Dalam sejarahnya propaganda hoax pun bisa dipakai untuk menjatuhkan kekuasaan yang sedang berkuasa. Publisitas yang tinggi diawal dan membawa seseorang pada kekuasaan dapat hilang dalam sekejap dengan propaganda yang terus menerus dilakukan secara berulang dan berkesinambungan.

Hubungan opini publik dan propaganda sangatlah erat sekali dan tidak bisa dipisahkan satu sama lain. Laswell (1927) pernah mengatakan bahwa propaganda semata-mata adalah kontrol opini. Ini artinya, suatu propaganda dilakukan untuk mempengaruhi dan mengontrol opini pihak yang menjadi sasaran propaganda. Misanya, propagandis mempropagandakan bahwa demi keadilan dan kebenaran maka demokrasi harus ditegakkan. Awal kegiatan yang dilakukan jelas mempersiapkan opini terlebuh dahulu dan kemudian dilontarkan untuk mempengaruhi opini publik. Jika opini publik sudah terbentuk secara baik bahwa memang perlu ditegakkan demokrasi, baru kemudian akan berpengaruh pada sikap dan perilaku masyarakat yang opininya sudah terbentuk.

Dengan demikian, opini publik bisa dikatakan menjadi perantara perubahan sikap dan tingkah laku sasaran propagandis. Dengan kata lain pula, opini publik menjadi alat yang baik dalam mewujudkan propaganda. Propaganda bertujuan untuk mempengaruhi opini publik. Perkembangan selanjutnya, opini publik yang sudah terbentuk untuk mendukung tujuan propaganda itu sendiri. Propaganda tidak saja sekadar bertujuan untuk mengomunikasikan fakta-fakta kepada 
publik, tetapi juga fakta-fakta yang mempengaruhi opini publik terhadap suatu isu tertentu. Perubahan pendapat umum itu bisa positif bisa juga negatif.

Propaganda dalam pemilihan Pilpres 2019 dilakukan juga bertujuan untuk dapat manipulasi emosi, bahkan sering dilakukan dengan cara yang membahayakan. Melalui teknik propaganda para propagandis "memanipulasi" kata, suara, simbol, serta pesan nonverbal agar dapat membangkitkan emosi pembaca. Apalagi ditambah kemampuan buzzer dan influencer mengelola dan menarasikan informasi propaganda tersebut. Keberadaan buzzer dan influencer sangat dibutuhkan dalam pertarungan pemenangan di dunia politik, terlebih semakin berkembangnya e-demokrasi. Berkampanye di dunia media baru cenderung lebih murah dan praktis. Buzzer bekerja dengan cara memberikan informasi berulang ulang agar menjadi viral atau trending, sehingga ramai diperbincangkan oleh banyak orang.

Dalam kampanye Pemilihan Presiden 2019, buzzer dan influencer di daerah khususnya di kota Medan kurang termaksimal dengan baik, tidak adanya tim khusus mengelola buzzer dan influencer di tingkat lokal, issue yang selalu dibangun merupakan secara tersentral, buzzer dan influencer lokal jika mempunyai keinginan membagikan issue tersebut hanya keinginan pribadi, jika informasi itu sesuai dengan pemikiran mereka, malahan ada beberapa buzzer dan influencer tingkat lokal, membuat konten khusus menganai calon yang disukainya untuk memberikan kesan positif di masyarakat, harapannya dapat mengupgrade ketokohan calon tersebut, sehingga disukai masyarakat pemilihnya, padahal pengelolaan buzzer dan influencer tingkat daerah itu sangat perlu dilakukan, karena hanya orang lokal atau setempat yang sangat memahami karakteristik pemilih dan masyarakat di daerah tersebut.

Buzzer hoaks tidak ada di kota Medan, yang ada hanya influencer sesuai dengan karakteristik masyarakat kota Medan yang lebih realistis dalam memandang sesuatu, alasan utama jika mereka jadi buzzer itu tidak aman terhadap pribadi mereka karena melihat bagaimana giatnya aparat kepolisian selalu mengejar pelaku buzzer politik yang menggunakan propaganda hoaks. Hal ini senada dengan hasil Focus Group Discussion yang dilakukan peneliti dengan pihak buzzer, influencer dan akademisi

Tujuan penggunaan hoaks dalam propaganda politik selaras dengan pemikiran teori propaganda Harold Lasswell, seorang pakar politik pertama yang mengenal manfaat berbagai teori psikologi dan menunjukkan implementasinya untuk memahami politik. Kekuatan propaganda bukanlah hasil dari substansi, isi, atau satuan pesan secara spesifik, tetapi disebabkan oleh pemikiran masyarakat umum yang sangat mudah dipengaruhi. Pemikiran ini dapat diperkirakan menggunakan teori psikologi. Lasswell berpendapat bahwa tekanan ekonomi serta peningkatan konflik politik menyebabkan tekanan mental yang meluas, dan hal ini membuat banyak orang dengan mudahnya melakukan propaganda kasar.

\section{Materi atau Konten yang digunakan sebagai Propaganda Hoaks}

Pemanfaatan media baru secara masif untuk kepentingan kampanye dalam konteks kompetisi politik berbasis figur sangat rentan dengan penyebaran propaganda hoaks yang memuat kampanye negatif dan kampanye hitam. Kementerian Komunikasi dan Informatika (Kominfo) mengidentifikasi 62 konten hoaks tersebar di internet dan media sosial sejak Agustus sampai Desember 2018. Dari mesin pengenal konten negatif yang berada di Sub-Direktorat Pengendalian Konten Internet Direktorat Pengendalian Ditjen Aplikasi Informatika Kemkominfo diketahui konten hoaks terkait pemilu terbanyak ditemukan pada Desember 2018.

Mantan Ketua MK, Mahfud MD berbicara soal kampanye negatif dalam Pilpres 2019. Bagi Mahfud, negative campaign tidak dilarang karena berbeda dengan kampanye hitam atau black campaign. Menurut beliau kampanye hitam adalah kampanye yang penuh fitnah dan kebohongan tentang lawan politik sedangkan kampanye negatif adalah kampanye yang mengemukakan sisi negatif/kelemahan faktual tentang lawan politik. Kampanye negatif tidak dilarang dan tidak dihukum karena memang berdasar atas fakta, yang bisa dihukum adalah kampanye hitam," kata Mahfud lewat twitternya. Mahfud juga memberi contoh apa yang dimaksud kampanye negatif dan kampanye hitam. Begini perbandingannya: "Kalau anda bilang bahwa Jokowi PKI atau bilang bahwa 
Prabowo terlibat ISIS, itu adalah kampanye hitam. Tapi kalau anda bilang Jokowi kerempeng atau bilang Prabowo kalah terus dalam pilpres, maka itu kampanye negatif. Kampanye hitam bisa dipidana, kampanye negatif bisa dilawan dengan argumen," ucapnya. (news.detik.com/ 2018/10/15)

Sebelum membuat konten, maka harus dibedakan apakah konten tersebut terkategori dalam ranah kampanye negatif atau kampanye hitam. Konten yang terbangun oleh para buzzer dan influencer tersebut ternyata tidak ada hubungannya terkait dengan visi misi pasangan calon. Konten tersebut hanya berisikan konten ringan yang sifatnya hanya dapat mengupgrade atau mendowngrade ketokohan calon. Hal ini dilakukan mengingat bahwa masyarakat Indonesia masih kurang memahami politik dengan baik.

Bentuk materi/konten dalam kampanye negatif seperti penuturan para informan diatas kepada peniliti diperkuat dengan bukti laporan isu-isu hoaks yang ditemukan selama pemilihan presiden RI tahun 2019. Contoh isu hoaks terkait Jokowi adalah PKI yang banyak beredar di media sosial ditemukan pada media sosial facebook dan laman berikut ini pada tanggal 7 Januari 2019 yang memuat artikel pada situs laman https://www.merdeka.com/cek-fakta/hoakspidato-jokowi-sebut-pki-tidak-bersalahapalagi-mengancam.html mengunggah sebuah tangkapan layar berita sebagai berikut:

Telah beredar di media sosial sebuah artikel situs yang menerangkan bahwa jokowi telah mengatakan PKI itu tidak Bersalah apalagi mengancam, yang berbahaya itu Islam Radikal. Pihak Istana melalui Sekretariat Presiden, Jokowi tidak berbicara soal PKI. Apalagi membela PKI dan mengatakan PKI sebagai korban. Jokowi membahas ancaman terhadap Pancasila secara umum. Termasuk infiltrasinya lewat media sosial dan tidak membahas terkait PKI dalam Pertemuan Pimpinan Perguruan Tinggi se-Indonesia di Bali, Selasa (26/9) lalu dan kesimpulannya hal itu tidak benar dan Jokowi tidak pernah mengatakan hal tersebut.

Dalam pemilihan presiden 2019, media baru semakin mengambil perannya dan menjadi bagian penting dalam strategi pemenangan pemilu. Meski belum optimal, pemerintah telah melakukan antisipasi dan melarang (banned) akun-akun manipulatif (clones) serta menghapus informasi palsu (hoaks) Para buzzer menggulirkan konten propaganda bernada provokatif semakin marak pada Pilpres 2019,

Keadaan perpolitikan di Indonesia peran pengaruh politik identitas dengan dasar agama sangatlah dominan untuk menarik simpati rakyat Indonesia. Dalam konteks tersebut politik identitas telah mewarnai dalam hal mengeksploitasi dan mempengaruhi perilaku seseorang dalam menetukan siapa pemimpinnya. Merujuk pada politik identitas dalam Pilpres 2019 dimana kedua kubu (Jokowi dan Prabowo) memanfaatkan isu Suku, Ras, Agama, dan Antar golongan (SARA) untuk mempengaruhi perilaku pemilih di Pilpres 2019. Terlebih mayoritas penduduk Indonesia merupakan pemeluk agama Islam (sekitar 88\%) adalah sebuah konsekuensi logis ketika menjelang pemilihan umum (Pemilu), suara umat Islam menjadi rebutan para aktor maupun partai politik dalam rangka mendulang dukungan, isu terkait konflik identitas agama dalam ranah politik begitu dominan baik kubu Jokowi-Ma'ruf maupun Prabowo-Sandi sama-sama berusaha untuk membangun image tentang keberpihakan terhadap Islam. Hadiz \& Rakhmani (2017) memprediksi nuansa politik identitas, baik dalam Pilkada Serentak 2018 maupun Pilpres 2019 akan tetap menjadi isu yang amat penting digunakan oleh para politisi.

Politik identitas merujuk pada pengertian terdapat sebuah ruang yang mempertemukan ketimpangan ekonomi dan ketidakadilan sosial yang terus menerus berlangsung, serta berkorelasi dengan diproduksinya sentimen identitas dan simbol keagamaan dalam rangka mendapatkan kekuasaan dan sumber daya politik (Hadiz \& Rakhmani, 2017). Misalnya klaim pihak Prabowo yang didukung oleh Ijtima' Ulama yang diselenggarakan Gerakan Nasional Pengawal Fatwa. Di kubu Prabowo-Sandi, dua isu utamanya adalah wacana yang telah lama berusaha dibangun bahwa mereka mendapatkan dukungan dari para ulama dan umat Islam di Indonesia. Ulama (GNPF-Ulama) sekaligus menyerukan terhadap umat Islam di Indonesia untuk mendukung Prabowo-Sandi, setelah Prabowo menandatangani pakta integritas, maka semenjak itu GNPF-Ulama secara resmi menyatakan bahwa mereka mendukung Prabowo-Sandi dan menyerukan 
terhadap umat Islam di Indonesia untuk mendukung pasangan yang didukung para ulama, Selain itu, isu dikriminasi ulama dan rezim yang tidak pro-Islam menjadi serangan bagi kubu Jokowi-Maaruf, sekaligus penguatan figur Prabowo menjadi Capres pembela ulama dan umat Islam. Di sisi lain, pihak JokowiMa'ruf juga mengklaim bahwa mereka sebenarnya didukung ulama, terlebih kapasitas Maa-ruf Amin sebagai pimpinan Majelis Ulama Indonesia, dan bahkan kubu Jokowi-Ma'aruf meragukan kredibilitas sekumpulan ulama yang mendukung Prabowo-Sandi.

Sebuah akun facebook mengunggah postingan dengan narasi bernada SARA tentang calon Presiden nomor urut 02 Prabowo Subianto. Dalam gambar yang di unggah disebutkan bahwa Prabowo Subianto adalah Keturunan Cina dan beragam Kristen. Setelah dilakukan penelususaran biografi Prabowo Subianto pada laman wikipedia.org ditemukan bahwa Prabowo Subianto merupakan anak ketiga dan putra pertama dari Soemitro Djojohadikusumo dan Dora Marie Sigar, yang lebih dikenal sebagai Dora Soemitro. Keluarga Djojohadikusumo sendiri dikatakan merupakan keturunan dari Raden Tumenggung Kertanegara, seorang panglima laskar Pangeran Diponegoro di wilayah Kedu; dan Adipati Mrapat, Bupati Banyumas yang pertama. Adapun Prabowo sendiri telah menegaskan bahwa ia beragama Islam meskipun saudaranya beragama katolik.

Contoh bentuk lain dari teknik penjulukan (name calling) yang terdapat pada materi/konten dalam propaganda hoaks pada pemilihan presiden RI tahun 2019 adalah simbol 02 jari milik pasangan Prabowo-Sandi identik dan menyerupai tembakan atau pistol.

Sebuah meme bergambarkan Capres nomor urut 02 Prabowo Subianto dengan tambahan narasi berbunyi "jika 2019 saya menjadi Presiden, Siapapun yang berani mengkritik saya akan ditembak". Hal ini tentu mengundang kontroversi di kalangan netizen terutama menjelang Pilpres 2019. Beberapa juga menyebutkan bahwa simbol 02 jari milik pasangan Prabowo Sandi identik dan menyerupai tembakan atau pistol. Dilansir dari republika.co.id, Wakil Ketua Umum DPP Partai Gerindra, Fadli Zon, Fadli menganggap salam dua jari yang dilakukan Prabowo sama dengan yang dilakukan mantan perdana menteri Inggris Winston Churchil. Menurut dia, lambang "V" yang terbentuk karena lekukan jari telunjuk dan jari tengah itu pertama kali digunakan oleh Winston Churchill sebagai doktrin bahwa Inggris akan memenangkan perang di Perang Dunia 2 melawan Jerman di Eropa.

Selain penggunaan teknik propaganda diatas, terdapat pula teknik propaganda lainnya yakni Testimonial; sebagai salah satu teknik propaganda lainnya yang materi/kontennya berisikan cara untuk memperoleh ucapan orang yang dihormati. Seperti kita ketahui bersama kedua pasangan calon baik pasangan calon 01 maupun 02 selalu merebut suara umat islam dan wacana politik yang disampaikan sesuai dengan Van Dijk (1997) menjelaskan bahwa analisis wacana politik berusaha untuk menguak wacana politik secara kritis. Sebagai perspektif yang lebih spesifik berbicara tentang analisis wacana politik sekaligus membedakannya dengan analisis-analisis dalam subjek kajian lain, Van Dijk merumuskan empat dimensi utama di dalam analisis wacana politik yakni dimensi aktor, audience, teks atau pernyataan, dan konteks. Aktor disini merujuk pada pengertian aktor politisi, seseorang yang menduduki jabatan politik maupun memiliki pengaruh politik di masyarakat. Aktor politik di kubu Jokowi-Ma'ruf dalam rangka pembingkaian wacana Islam terutama Ma'ruf Amin. Sedangkan di kubu Prabowo-Sandi, dua kandidat Capres dan Cawapres itu tidak menjadi pemain kunci dalam memainkan peran tersebut, tapi orang-orang di sekitar mereka, lebih spesifik lagi diantaranya adalah GNPF-Ulama.

Dimensi kedua adalah teks wacana, baik berupa perkataan maupun tulisan yang menjadi basis narasi. Di kubu Jokowi-Ma'ruf, dua isu utama dalam untuk menunjukkan posisi pembelaannya terhadap Islam dan umat Islam adalah dengan mempopulerkan wacana ekonomi syariat dan narasi nasionalisme religius untuk membendung paham Islam radikalisme dan Islam garis keras di kubu sebelah, sembari mengkampanyekan guna menjaga kedaulatan dan persatuan NKRI. Di kubu Prabowo-Sandi, dua isu utamanya adalah wacana yang telah lama berusaha dibangun bahwa mereka mendapatkan dukungan dari para ulama dan umat Islam di Indonesia. Selain itu, isu tentang rezim yang tidak pro-Islam 
menjadi serangan bagi kubu Jokowi-Ma'ruf sekaligus penguatan figur Prabowo menjadi Capres pembela ulama dan umat Islam, seperti terlihat pada konten/materi yang beredar di twitter dan laman berita on-line pada tanggal 16 Januari 2019.

Dalam media sosial twitter diatas beredar video yang merekam aksi jamaah Tablig Akbar Persaudaraan Alumni (PA) 212 di Solo Raya terhadap sekelompok polisi yang bertugas menjaga keamanan. Dalam video tersebut tampak jamaah protes karena merasa dihalangi untuk mengikuti acara tersebut. Pada unggahan juga disertai berbagai narasi provokatif yang mengatakan bahwa kejadian tersebut adalah bukti bahwa rezim Jokowi benar anti Islam.

Faktanya acara tersebut berlangsung lancar. Adapun memang terdapat adanya pengamanan ketat dari pihak kepolisian. Wakapolresta Surakarta, AKBP Andy Rifai, menjelaskan bahwa penyekatan di batas kota dilakukan karena acara tersebut ilegal. Polisi telah meminta panitia mengajukan surat izin, namun tak diindahkan. Ia juga mengatakan bahwa kegiatan tersebut termasuk ilegal sebab tidak ada izin resmi sesuai UU nomor 22 tahun 2009 tentang lalu lintas dan Peraturan Kapolri nomor 10 tahun 2012 tentang penggunaan jalan diluar fungsinya". Dia menilai justru kepolisian sudah memberikan kelonggaran kepada panitia sehingga acara tetap bisa berjalan. Polisi pun membatasi waktunya sampai pukul 09.30 WIB.

Maraknya isu wacana Islam yang mewarnai pemilihan Presiden 2019 maka dapat diklasifikankan ke dalam tabel. Berikut tabel yang dapat menyederhanakan analisis wacana politik dalam melihat pertarungan wacana Islam:

Tabel 4.1 Analisis Wacana Politik dalam Pilpres 2019

\begin{tabular}{llll}
\hline No & $\begin{array}{l}\text { Dimensi } \\
\text { Analisis } \\
\text { Wacana }\end{array}$ & $\begin{array}{l}\text { Jokowi- } \\
\text { Maaruf }\end{array}$ & $\begin{array}{l}\text { Prabowo- } \\
\text { Sandi }\end{array}$ \\
\hline 1 & $\begin{array}{l}\text { Aktor } \\
\text { Politisi }\end{array}$ & Maaruf- Amin & $\begin{array}{l}\text { GNPF- } \\
\text { Ulama }\end{array}$ \\
\hline 2 & Wacana & Nasionalisme & Membela \\
& & - Religius & $\begin{array}{l}\text { Ulama dari } \\
\text { Diskriminasi }\end{array}$ \\
\hline 3 & Konstituen & Islam & Islam
\end{tabular}

Dalam sebuah pergulatan wacana, pasti terdapat dua kekuatan atau kekuasaan yang sedang berusaha mengendalikan wacana. Artinya setiap wacana yang bergulir tersebut harus dilihat bersifat sementara dan menjadi arus utama wacana yang digulirkan. Misalnya, tentang wacana siapa yang paling didukung ulama, siapa yang paling memiliki keberpihakan terhadap ulama dan umat Islam dan seterusnya, keseluruhan harus masuk dalam proses sebuah pergulatan kontestasi yang berlangsung. Hal ini menegaskan bahwa suatu wacana tidak selalu hanya hadir melalui satu kekuasaan tunggal. Sebagaimana dijelaskan Mills (2001), setiap wacana akan mendapatkan perlawanan wacana dari kelompok lain sebagai upaya mencounter wacana dominan tersebut. Wacana tentang gerakan feminisme misalnya, sebuah wacana kekuasaan yang lain guna menandingi kekuasaan dominan berupa budaya patriarki yang begitu kuat. Begitu juga dengan wacana pos-kolonial, sepeti orientalisme Edward Said yang merupakan narasi tandingan terhadap pemikiranpemikiran para kolonial dan mapannya budaya Barat. Sama halnya dengan pergulatan didalam internal wacana Islam tertentu, wacana tersebut mengalami pertarungan kekuasaan antara wacana yang dominan dengan counter wacana yang menghadangnya.

Name calling atau penjulukan kata 'cebong' untuk para pendukung JokowiMa'aruf dan penjulukan 'kampret' untuk pendukung Prabowo-Uno. Menurut Wawan Masudi seorang pengamat politik dari Universitas Gadjah Mada mengatakan bahwa sebutan cebong dan kampret dari awal dilakukan netizen untuk mengelompokkan perbedaan pilihan politik masyarakat dan labelisasi semacam ini cukup menghangatkan situasi politik menjelang Pemilihan Umum (Stefanie, 2018). Cebong sebagai sebuah istilah ternyata dimunculkan oleh kubu yang anti Joko Widodo dengan tujuan mengejek pendukungnya. Istilah ini dipakai tidak lepas dari kebiasaan Joko Widodo sendiri yang memiliki hobi memelihara kodok dan cebong di kolam istana negara supaya dapat merasakan suasana pedesaan yang dulu melekat dalam kehidupan Joko Widodo. Sedangkan istilah kampret merupakan binatang sejenis kelelawar yang suka tidur dengan posisi terbalik kaki diatas, yang digunakan untuk memberi label terhadap seseorang yang sering menggunakan logika 
terbalik. Konten materi tersebut terlihat pada akun facebook yang beredar di media sosial tertanggal 5 Januari 2019.

Telah beredar sebuah postingan di media sosial facebook yang merupakan gabungan dari beberapa foto dengan ditambahkan narasi: "Buat cebong jangan nyinyir terus kalo bukti udah di tangan kita kalian mau apa kalian jual saya borong, buat saudarku rapatkan barisan jangn di kasi kendor dan buat alumni 212 pantau terus sampek pilpres selesai Insha Allah kemenangan ada ditangan kita amin yarabbalamin"

Setelah ditelusuri ternyata terdapat misinformasi antara satu gambar dengan gambar yang lain. Pemosting membagikan foto peristiwa tahun 2015 mengenai Surat suara pilkada Tangsel Gelombang Pertama Tiba, membagikan isu yang sudah terbukti hoaks seperti foto mengenai isu kontainer surat suara. Kemudian pemosting menambahkan narasi yang tidak ada hubungannya dengan konteks asli dari foto yang digunakan.

Saling memberi label hewan cebong dan kampret menjadi fenomena politik khas yang hanya terjadi di Indonesia. Wawan Masudi mengatakan bahwa fenomena politik semacam ini hampir tidak pernah terlihat dalam Pemilihan Umum di negara lain, setidaknya di Australia dan Norwegia (Stefanie, 2018) yaitu menggunakan istilah-istilah hewan untuk menyebut atau mengolok-olok orang yang berbeda pilihan politiknya. Hal ini terindikasi bahwa rakyat Indonesia belum matang dalam berdemokrasi.

Teknik propaganda Transfer berisikan materi konten yakni mengidentifikasi suatu maksud dengan lambang otoritas. Peneliti melihat disini lebih kepada lambang tagar \#2019gantipresiden merupakan bentuk propaganda yang massive di masyarakat dari kubu Prabowo-sandi, dikubu Joko-Ma'ruf dengan tagar \#jokowi_2Periode.

Dan juga tidak kalah serunya ketika Jokowi berbicara tentang politik genderuwo, Jokowi kembali melontarkan pernyataan yang bikin geger. Setelah menyebut adanya 'politikus sontoloyo', kini dia berbicara tentang 'politik genderuwo'. Jokowi mengatakan bahwa berpolitik itu jangan menakuti rakyat yakni menimbulkan ketakutan dan kekhawatiran sehingga menimbulkan ketidakpastian. Jokowi tidak mengarah kepada siapa pun dalam pernyataannya ini. Namun tetap saja pernyataan tokoh capres nomor urut 01 ini mengundang reaksi dari kubu rivalnya. Saat Jokowi ditanya, 'politik genderuwo' yang dia maksud adalah cara-cara berpolitik yang menggunakan propaganda yang menakutnakuti. Politik semacam ini juga menimbulkan keraguan di tengah masyarakat (detik.com/2018/11/09).

Teknik propaganda transfer berisikan materi konten yakni mengidentifikasi suatu maksud dengan lambang otoritas, seperti salam dua jari yang diidentikkan dengan dukungan kepada salah satu calon presiden dan wakil presiden pada pilpres 2019 yakni pasangan Prabowo-Sandi. Konten/materi tersebut tampak pada akun facebook yang beredar di media sosial tertanggal 12 Januari 2019, sebagai berikut:

Telah beredar sebuah foto di akun Facebook yang menampilkan Panglima TNI Marsekal Hadi Tjahjanto dan dua petinggi TNI lainnya menunjukkan salam dua jari (membentuk huruf L) dengan menambahkan narasi seolah tokoh-tokoh tersebut mendukung salah satu calon presiden dan wakil presiden Indonesia pada pilpres 2019 mendatang, yakni Prabowo-Sandi. Panglima TNI Marsekal Hadi Tjahjanto menegaskan dan mengklarifikasi bahwa foto tersebut memiliki makna kebersamaan, tidak ada maksud lain dan diambil sebelum paslon mengambil nomor urut pilpres 2019. Ia juga menegaskan bahwa TNI dan Polri netral pada pemilu 2019. "Saya sampaikan bahwa TNI-Polri tetap menjaga netralitas dan simbol-simbol yang digunakan leting 87, angkatan 92 dan Lemhannas angkatan 20, itu adalah simbol untuk kebersamaan, tidak ada maksud lain dan diambil sebelum paslon mengambil nomor urut". Jadi tidak benar bahwa foto (salam dua jari) yang sedang beredar di sosial media tersebut mendukung atau mengkampanyekan salah satu paslon pilpres 2019.

Selain teknik propaganda di atas, terdapat pula penggunaan teknik propaganda lainnya yakni Testimonial, sebagai salah satu teknik propaganda lainnya yang merupakan suatu cara untuk memperoleh ucapan orang yang dihormati atau dibenci untuk mempromosikan atau meremehkan suatu maksud. Kita mengenalnya dalam dukungan politik oleh media mainstream, tokoh terkenal, dan lain-lain. Keuntungan jokowi sebagai 
petahana beliau dapat meminta pendapat koleganya, hal ini dapat dilihat pada pernyataan Presiden Bank Dunia Jim Yong Kim akan Jokowi dan perhelatan IMF-WB 2018 Annual Meetings yang dilakukan di Bali pada 8-14 Oktober 2018. Beliau mengatakan bahwa Presiden Jokowi telah menjadi pemimpin dalam modal manusia, dalam manajemen bencana, dalam cara-cara yang menurut kami sangat baik. Beliau juga menambahkan bahwa keadaan ekonomi Indonesia sudah lebih baik dan kuat jika dibandingkan dengan tahun 1998 dan 2008. Pernyataan yang juga mengukuhkan legitimasi atas kepemimpinan Jokowi datang dari Direktur Pelaksana IMF, Christine Lagarde. Beliau mengatakan bahwa pinjaman dari IMF bukan pilihan karena ekonomi Indonesia tidak membutuhkannya. Ekonomi Indonesia dikelola dengan sangat baik oleh Presiden Jokowi dan rekan-rekan (cnnindonesia.com, 2018, terbit 09 Oktober 2018). Kedua pernyataan di atas secara tidak langsung merupakan dukungan tidak langsung terhadap kinerja Jokowi dan kabinetnya atas perekonomian Indonesia maupun sosok beliau. Kinerja beliau yang dirasa baik dan kuat menjadi prestasi yang menjadi agenda untuk disampaikan ke masyarakat. Konten materi seperti ini terdapat pada artikel yang diposting di akun facebook atas nam Ferry Batara Manurung tertanggal 23 Januari 2019

Telah beredar artikel yang diposting oleh akun facebook yang menytakan bahwa itu pernyataan yang disampaikan Wakil Presiden Jusuf Kalla ketika memberikan sambutan diacara simposium Simposium Ekonomi yang diadakan oleh MPR RI pada tahun 2017. Redaksi yang dituliskan dalam artikel ini terindikasi disinformasi karena tidak sesuai dengan apa yang disampaikan Wakil Presiden Jusuf Kalla pada saat memberikan sambutan. Faktanya Wakil Presiden Jusuf Kalla tidak pernah menulis dan menyampaikan sentimen buruk terhadap Presiden SBY dan Suharto pada sambutannya di acara Simposium Ekonomi tersebut.

Plain folks merupakan teknik propaganda yang berisikan konten materi terkait imbauan yang mengatakan bahwa pembicara berpihak kepada khalayaknya dalam usaha bersama yang kolaboratif. Dari definisi di atas dan dihubungkan dengan konteks Jokowi-Ma'ruf Amin secara sederhana bisa dilihat pemberian Kartu Indonesia Sehat
(KIS) dan Kartu Indonesia Pintar (KIP) yang akan terus dilakukan jika keduanya terpilih menjadi Presiden dan Wakil Presiden Republik Indonesia, dan komitmen Jokowi-Ma'ruf Amin terhadap kemajuan negara, kesehatan, dan pendidikan. Hal lain juga bisa dilihat atas pembentukan Badan Ekonomi Kreatif (Bekraf). Pemerintah dinilai sudah menunjukkan keberpihakan terhadap usaha kecil dan perusahaan rintisan yang dibangun akan-anak muda. Presiden Jokowi memahami bahwa suara terbesar pada pemilu 2019 ialah ibu-ibu dan generasi milenial sehingga beliau melakukan pendekatan yang memang sudah sejak awal. Untuk Kartu Indonesia Sehat (KIS) dan Kartu Indonesia Pintar (KIP). Pembangunan infrastruktur di berbagai wilayah di Indonesia juga merupakan program kerja Jokowi yang terlihat hasilnya. Namun konten berita yang menjatuhkan hasil kerja pemerintahan Jokowi pada bidang infrastruktur dapat terlihat pada postingan di akun facebook atas nama Eri Iskandar tertanggal 19 Januari 2019 sebagai berikut:

Sebuah akun memposting kiriman gambar jembatan widang babat ambruk yang disertai narasi mengenai pembangunan infrastruktur kejar tayang untuk pilpres 2019 yang dilakukan oleh Jokowi.

Faktanya Jembatan Cincin Lama yang ambrol sudah dibangun sejak tahun 1970-an. Namun jembatan yang menghubungkan ruas Tuban-Widang ini diyakini masih bisa dioperasikan hingga puluhan tahun lagi. Direktur Jembatan Ditjen Bina Marga Kementerian Pekerjaan Umum dan Perumahan Rakyat (PUPR), Iwan Zarkasi mengatakan jembatan tersebut dibangun saat masa orde baru dalam program Pelita (pembangunan 5 tahun). Saat itu pemerintah mengimpor langsung bahan jembatan itu dari Inggris.

Contoh lain dari program kerja pemerintahan Jokowi adalah program BPJS yang memberikan pengobatan gratis kepada masyarakat. Konten materi yang berisikan isu hoaks terdapat pada berita on-line tertanggal 31 Januari 2019 seperti terlihat dibawah ini:

Belakangan masyarakat dihebohkan dengan aturan baru di Badan Penyelenggara Jaminan Sosial (BPJS) Kesehatan mengenai urun biaya dan selisih biaya yang termaktub dalam Peraturan Menteri Kesehatan (Permenkes) Nomor 51 tahun 2018. 
Sebagaimana dituangkan dalam Permenkes bahwa berlaku tarif Urun biaya atau beban tarif $\mathrm{Rp} 20.000$ setiap kali pasien melakukan kunjungan rawat jalan di RS kelas A dan B. Untuk RS kelas C dan D Besarannya relatif murah yakni Rp. 10.000 sekali rawat jalan. Selain itu, juga berlaku maksimal kunjungan rawat jalan 20 kali. Batas jangka waktu kunjungan tiga bulan. Beban biaya paling tinggi sebesar Rp 350.000.

Meski hal tersebut adalah benar, namun Kementerian kesehatan menegaskan bahwa aturan mengenai urun biaya belum diberlakukan. Hal ini disebabkan jenis pelayanan apa yang akan dikenakan urun biaya belum ditetapkan oleh Menteri Kesehatan, dalam arti lain Permenkes 51 ini masih dalam penggodokan.

Jenis teknik propaganda lain yang digunakan dalam pemilihan presiden RI 2019 adalah Bandwagon sebagai teknik propaganda yang berisikan konten materi terkait usaha untuk meyakinkan khalayak akan kepopuleran dan kebenaran tujuan sehingga setiap orang akan percaya melalui teknik propaganda tersebut. Dan dapat dilihat terdapat gerakan yang bermunculan di saat ini menjelang pemilihan presiden tahun 2019 mendatang, salah satunya yakni gerakan \#2019gantipresiden, dan dikubu jokowi tagar \#Jokowi2periode, atau \#diasibukkerja. Gerakan ini mempunyai dua sisi yang berbeda, artinya ada yang menganggap sebagai wajar dan merupakan sebuah ekspresi politik. Selain itu terdapat pula yang menganggap bahwa gerakan ini cenderung memunculkan sebuah kekhawatiran. Dan berpotensi sebagai gerakan kampanye hitam serta rentan memancing provokasi. gimana ibu yang mengenakan kaus \#DiaSibukKerja mendapat intimidasi dari massa kaus \#2019GantiPresiden di Car Free Day, Bundaran HI, Minggu pagi (Amanaturrosyidah, 2018). Neno Warisman salah satu deklarator \#2019GantiPresiden juga mendapat penolakan di Batam hingga Pekanbaru ketika ingin menghadiri tabligh akbar dan deklarasi \#2019GantiPresiden (Nugroho \& Siagian, 2018). Ahmad Dhani salah satu inisiator \#2019GantiPresiden di Surabaya juga ditolak oleh kelompok masyarakat yang tidak setuju dengan gerakan tersebut, bahkan sempat terkepung di hotel tempat dia menginap (Ferry \& Sumirat, 2018).
Hal senada muncul pada postingan diakun media sosial yang berisikan materi/konten yang mengidentifikasi suatu maksud dengan lambang otoritas seperti tanda pagar \#01Jokowilagi, \#2019JokowiMarufAmin (Erond, 2018).

Salah satu akun dalam media sosial telah menyebarkan kembali sebuah video disinformasi terkait pidato prabowo yang membahas tentang strategi "Loot a burning house" yang berarti "rampoklah rumah yang sedang terbakar" dimana dalam postingan itu membangun premis bahwasannya prabowo adalah orang yang jahat.

Faktanya adalah ini hanyalah disinformasi dalam menginterpretasi pidato dari pada bapak prabowo karena video yang diambil adalah hanya sepenggal dari seluruh isi pidatonya. Saat itu Prabowo mengutip dari sumber "Thirty-Six Stratagems" yaitu esai bahasa Cina yang digunakan untuk menggambarkan serangkaian tipu muslihat yang digunakan dalam interaksi politik, perang, dan sipil. Konteks sesungguhnya adalah pidato Prabowo di acara "Dialog para pejuang "Nasionalisme: Kembalikan Indonesia. Pada intinya tujuannya adalah bagaimana menjaga bangsa kita ini.

Menurut Jean Baudrillard, yakni salah seorang tokoh yang memaparkan pemikirannya tentang konsep simulacra/ simbol dalam masyarakat modern. Menurutnya, sebuah kenyataan sudah tergantikan sebuah manipulasi yang nyata, dan dipelopori sebuah simbol. Jean Baudrillard juga memaparkan pemikirannya mengenai simbol - simbol yang membahas mengenai teknologi, hal ini diwujudkan oleh hiperealitas dan simulasi yang mengarah kepada sebuah realitas baik virtual maupun artifisial yang terdapat pada konsumsi massa dan komunikasi massa. Manusia dapat terbentuk dalam berbagai bentuk simbol karena realitas tersebut. Simulasi juga biasa disebut sebagai realitas yang pada awalnya bukan sebuah realitas yang sebenarnya. Hanya saja kesadaran manusia terbentuk melalui sebuah simbol. Baginya, kebohongan yang biasa terbentuk dikarenakan ketika mempresentasikan sebuah kejadian yang berubah menjadi sebuah informasi, manusia cenderung mengkonsumsi secara berlebihan. Dalam
dipaparkannya,

hiperealitas merupakan ideologi yang 
membahas mengenai sebuah kenyataan terdapat susunan dan simbol-simbol yang selalu berhubungan dengan simbol-simbol lain serta telah melewati kenyataan yang sesungguhnya. Sehingga suatu yang dikaji bukan memfokuskan kepada suatu sumber atau sebuah kenyataan saja, sebab hal ini merupakan sebuah pemikiran semu yang akhirnya berubah menjadi sebuah kenyataan.

Peran media baru dalam media sosial seperti Facebook dan Twitter sifatnya borderless (tanpa batas) menyebabkan efek distorsi fakta/realitas yang oleh berita hoaks bisa menjangkau audiens yang sangat luas, selain itu setiap orang bisa jadi wartawan, editor dan bahkan dapat dengan mudah menyebarluaskannya; karena sifat berita baik itu baik berita itu benar ataupun bohong, yang sifat utama berita sebagai informasi untuk memberikan pengetahuan kepada khalayak, maka berita hoaks sebagai diskursus publik bisa sebagai alat yang efektif memanipulasi pikiran (cognitive manipulation) publik untuk mempercayai sesuatu yang salah sebagai suatu kebenaran (believing a falsity as a truth).

Efek dari manipulasi kognitif ini adalah pikiran publik dikaitkan satu isu dengan isu lainnya atau dalam istilah lain atau biasa dikenal dengan rantai wacana dalam kajian analis wacana kritis, membuat kebingungan publik dan ragu informasi mana yang harus dicerna dan ini merupakan tujuan utama propagandais atau pembuat informasi propaganda hoaks. Dalam pemilihan umum Pilpres 2019 lazim selalu terjadi propaganda hoaks hanya seputaran masalah pribadi kandidat yang bertarung, hanya materi seputaran SARA, Personal, dan Penjulukan kandidat dengan menggunakan narasi negatif, bahkan bohong sebagai untuk melemahkan persepsi masyarakat terhadap kinerja pemerintah atau penguasa ini untuk kandidat 01, sedangkan untuk kandidat 02 digunakannya propaganda hoaks untuk mereduksi ketokohan dan kepopuleran kandidat 02. Issu yang dibangun hanya issue ringan, isu kepopuleran bukan Program kerja pasangan calon.

Hal ini sesuai dengan pendapat tokoh Aditya Perdana, pengamat dari Universitas Indonesia mengatakan pola ini terlihat dari saling serang yang menggunakan isu populis, bukan program serta propaganda hoaks. Menurut Aditya, model kampanye semacam ini pernah dilakukan Presiden AS Donald Trump dengan menyerang lawannya dengan isu-isu dan menggiring para pemilih pada tema seputar nasionalisme. "Itu kan cara atau strategi. Contohnya antek asing. Kalau kampanye Trump saat pemilihan kan mempertanyakan apakah Anda punya nasionalisme atau tidak ujar Aditya kepada BBC News Indonesia, Jadi nampaknya yang sedang dibangun isu populisme, bukan programatik. Memang mudah sekali isu seperti itu terangkat karena dekat dengan pemilih kan, apalagi soal identitas (bbc news/2019/02/05).

\section{Pola Penggunaan Propaganda Hoaks}

Propaganda hoaks yang selalu terjadi di ranah media baru dan dilakukan secara repetitive atau berulang-ulang sehingga membuat kebinguan di tengah masyarakat. Selaras dengan pendapat Jozef Goebbels, Menteri Propaganda Nazi di zaman Hitler, mengatakan: "Sebarkan kebohongan berulangulang kepada publik. Kebohongan yang diulang-ulang akan membuat publik menjadi percaya".

Tentang kebohongan ini, Goebbels juga mengajarkan bahwa kebohongan yang paling besar ialah kebenaran yang diubah sedikit saja. Seperti yang kita ketahui propaganda yang terjadi ketika pemilihan Presiden 2019, Informan yang diwawancarai oleh peneliti bersepakat bahwa kedua belah pihak samasama menggunakan taktik kampanye Propaganda Rusia teknik Fire House False Hood baik pasangan calon 01 maupun pasangan calon 02 .

Salah satu contoh yang memenuhi karakteristik firehouse of falsehood ini adalah kasus hoaks yang melibatkan Ratna Sarumpaet. Perkara ini tengah menjalani pemeriksaan di Pengadilan Jakarta Selatan dengan dakwaan 14 dan 15 Undang-Undang Nomor 1 tahun 1946 an Pasal 28 Ayat (2) juncto 45A Ayat (2) Undang-Undang Nomor 19 Tahun 2016 tentang Perubahan atas UndangUndang Nomor 11 Tahun 2008 tentang Informasi dan Transaksi Elektronik. Pada 2 Oktober 2018 sempat beredar foto dan pernyataan mengenai penganiayaan terhadap Ratna Sarumpaet. Berita yang beredar penganiayaan tersebut terjadi 21 September 2019 di Bandara Husein Sastranegara, Bandung. Berita ini disebarkan melalui multi- 
channel baik media berita resmi, viral di media sosial, hingga grup chat. Penyebaran berita ini berlangsung secara repetitive dan continuous, secara bergantian beberapa tokoh menyampaikan keprihatinan atas peristiwa tersebut dan diliput media, setiap pernyataan tokoh menjadi pemberitaan dan tersebar di berbagai media, termasuk akun media baru yang kemudian disebarluaskan (share).

Partai politik ikut berperan dalam memberikan pembelajaran politik terhadap masyarakat, adapun teknik penggunaan propaganda hoaks dalam pemilihan Presiden RI tahun 2019 adalah dengan menggunakan pola teknik penjulukan (name calling), transfer, testimonial, bandwagon, merakyat (plain folk), menumpuk kartu (card staking) dan imimg-iming (glittering generalities), dan hal tersebut dilakukan secara berulang-ulang dan berkesinambungan, seperti terlihat dalam tabel berikut:

Tabel 4.2 Pola Propaganda Hoaks dalam Pilpres 2019

\begin{tabular}{|c|c|c|c|}
\hline No. & Pola Propaganda Hoaks & Jokowi - Maaruf & Prabowo - Sandiaga \\
\hline 1 & Penjulukan (name calling) & $\begin{array}{l}\text { Cebong } \\
\text { Nasioalisme -Islam }\end{array}$ & $\begin{array}{l}\text { Kampret } \\
\text { Radikal - Anti NKRI }\end{array}$ \\
\hline 2 & Transfer & Maaruf Amin & GNPF - Ulama \\
\hline 3 & Testimonial & Kolega dalam pemerintahan & $\begin{array}{l}\text { Pengamat yang berseberangan } \\
\text { dengan pemerintah }\end{array}$ \\
\hline 4 & Bandwagon/ \#Tagar & $\begin{array}{l}\text { \#Jokowi2Periode } \\
\text { \#DiaSibukKerja }\end{array}$ & \#2019GantiPresiden \\
\hline 5 & Merakyat (plain folks) & $\begin{array}{l}\text { Kartu Indonesia Sehat Kartu } \\
\text { Indonesia Pintar } \\
\text { Sederhana } \\
\text { Blusukan }\end{array}$ & $\begin{array}{l}\text { Rakyat Butuh Pemimpin baru } \\
\text { (Rabu Biru) }\end{array}$ \\
\hline 6 & $\begin{array}{l}\text { Menumpuk Kartu } \\
\text { (card stacking) }\end{array}$ & Jokowi PKI & Pelanggar HAM \\
\hline 7 & $\begin{array}{l}\text { Iming-iming } \\
\text { (glittering generalities) }\end{array}$ & Kerja, kerja, kerja & Pembela Ulama \\
\hline 8 & $\begin{array}{l}\text { Terus-Menerus } \\
\text { /Berkesinambungan }\end{array}$ & & \\
\hline
\end{tabular}

\section{SIMPULAN}

Propaganda hoaks digunakan oleh para aktor sebagai propaganda politik bertujuan agar dapat dengan mudah mendoktrinasi pemilih, membentuk opini, memanipulasi emosi/psikologis, serta menaikkan atau menurunkan kualitas salah satu calon, terlebih terjadi pada saat pemilihan, baik kepala daerah maupun pemilihan presiden, dikarenakan masyarakat Indonesia belum bisa memaknai politik beserta dinamikanya secara mendalam. Tujuan propaganda politik hoaks selain mempengaruhi publik juga dilakukan untuk mengubah image negatif menjadi positif ataupun sebaliknya, agar meningkatkan elektabilitas dan kepopuleran calon yang didukung.

Kedua, materi atau konten yang digunakan sebagai propaganda hoaks adalah materi atau konten yang berisikan tentang SARA, personal, memakai pola penjulukan, transfer, iming - iming, narasi merakyat, dengan menggunakan konten berita/informasiyang sifatnya negatif bahkan tidak jarang berisi kebohongan dan itu dibagikan melalui semua media, terkhusus media baru sebagai alat untuk melemahkan persepsi masyarakat terhadap kinerja pemerintah atau penguasa ini untuk kandidat 01 petahana, sedangkan materi atau konten yang dipropagandakan untuk kandidat 02 bertujuan untuk mereduksi ketokohan dan kepopuleran calon kandidat tersebut.

Ketiga, pola penggunaan propaganda hoaks yang digunakan dalam pemilihan presiden 2019. Pola penggunaan propaganda hoaks ini dihembuskan dalam media baru dengan cara berulang ulang (repetitive) dan berkesinambungan/kontiniutas untuk mengubah pikiran kognitif dan membangkitkan emosi masyarakat yang kurang memahami pendalaman terhadap politik. Para propagandais tidak segan-segan untuk mengubah narasi pesan yang disampaikan, jika narasi propaganda hokas yang mereka sebarkan tidak mendapat perhatian publik. Propagandais mengunakan 
dengan beberapa teknik propaganda misalnya: teknik penjulukan (name calling), teknik transfer, testimonial, bandwagon, merakyat (plain folk), menumpuk kartu (card staking) dan imimg-iming (glittering generalities).

\section{DAFTAR PUSTAKA}

Allcott, H., \& Gentzkow, M. (2017). Social Media and Fake News in the 2016 Election. Report and Reseach. Diakses dari situs https://web.stanford.edu/gentzkow/research/fakenews.pdf, tanggal 23 April 2019.

APPJII: (2016). Infografis Panetrasi dan prilaku Pengguna Internet di Indonesia. Diakses dari situs:https://www.apjii.or.id/content/read/ 39/264/Survei-Internet-APJII-2016.

Atik, A. (2017). Hoaks dan Banalitas Kejahatan dalam jurnal Transformasi No.32 tahun 2017.

Azzyumardi, A. (2018). Ujaran Kebencian dan Kebebasan.

http://jurnaltoddoppuli,wordpress.com/201 5/11/06/Ujaran-kebencian-dan-kebebasan/ diakses 20 April 2019.

Bernard, H.R. (1998). Research Methods in Anthropology: Qualitative and Quantitative Approaches. Walnut Creek: AltaMira Press.

Block, D. (2019). Post-truth and Political Discourse. Switzerland: Palgrave Macmillan.

Chang, W. (2018). Media Use and Satisfaction with Democracy: Testing the Role of Political Interest. Social Indicators; Research, 140(3), 999-1016.

Damanik, E.L (2018). Hashtag \#2019GantiPresiden: Sentimen Anti-petahana dan Orientasi Politik Pemilih Pemula menghadapi Pilpres 2019 di Pematangsiantar. JPPUMA: JPPUMA: Jurnal Ilmu Pemerintahan dan Sosial Politik UMA (Journal of Governance and Political UMA), 6 (2): 166-176.

Feldman, L. (2017). How Donald Trump Fits in the 'Post-Truth' World. The Christian Science Monitor.

https://kumparan.com/beritajatim/apa-itugerakan-rabu-biru-dari-pasangan-prabowosandiaga-uno-1546423256087815864

https://majalah.tempo.co/read/157570/presidenrepublik-indonesia-joko-widodo-tugaspemimpin-bukan-memanaskan-suasana. Diakses pada tanggal 15 Mei 2019

https://nasional.kompas.com/read/2018/11/23/1 $5185081 /$ penjelasan-soal-foto-kampanyepki-dn-aidit-yang-terdapat-pria-miripjokowi (Kompas.com 23/11/2018)

https://news.detik.com/berita/d-4295392/gegerjokowi-bicara-genderuwo berpolitik

https://www.bbc.com/indonesia/indonesia47130878
https://www.csmonitor.com/USA/Politics/2017/0 126/How-Donald-Trump-fits-in-the-posttruth-world. Diakses pada Tanggal 6 Mei 2019

https://www.merdeka.com/dunia/jelang-pemilufacebook-dan-twitter-jadi-medan-tempurbuzzer-politik-jokowi-prabowo.html. Diakses pada tanggal 15 Mei 2019.

Kalpokas, I. (2019). A Political Theory of Post-truth. Switzerland: Palgrave Macmillan.

Kemendagri. (2017). Penelitian: Berita Hoaks Pengaruhi Opini Pembaca. Diakses dari situs http://litbang.kemendagri.go.id/website/pe nelitian-berita-hoaks-pengaruhi-opinipembaca/tanggal 23 April 2017. Diakses pada tanggal 23 April 2019.

Keyes, R. (2004). The Post-truth Era: Dishonesty and Deception in Contemporary Life. New York: St. Martin's Press.

Kompas.com dengan judul "Mengapa Kampanye Negatif Boleh, Kampanye Hitam Tak Boleh?", https://nasional.kompas.com/read/2018/1 0/15/14305051/mengapa-kampanyenegatif-boleh-kampanye-hitam-takboleh?page $=$ all

Lewandowsky, S., Ecker, U. K. H., dan Cook, J. (2017). Beyond Misinformation: Understanding and Coping with the 'Posttruth' Era. Journal of Applied Research in Memory and Cognition, 6(4), 353-369.

Lewandowsky, S., Ecker, U. K. H., Seifert, C., Schwarz, N., dan Cook, J. (2012). Misinformation and Its Correction: Continued Influence and Successful Debiasing. Psychological Science in the Public Interest, 13(3), 106-131

Louw, E. (2005). The Media and Political Process. London: Sage Publications

Mastel. (2017). Hasil Survey MASTEL Tentang Wabah Hoaks Nasional. Diakses dari situs: http://mastel.id/infografis-hasil-surveymastel-tentang-wabah-hoaks-nasional tanggal 2 Desember 2017.

McIntyre. L. (2018). Post-truth. Massachusetts: MIT Press.

Miriam, B. (1998). Partisipasi dan Partai Politik. Jakarta: Gramedia.

Moleong. L.J. (2007). Qualitative Research Methodology. Bandung: PT Remaja Rasdakarya Offset.

Nasrullah, R (2014). Teori dan Riset Media Siber (Cybermedia). Jakarta: Kencana.

Nimmo. (1989). Komunikasi Politik: Komunikator, Pesan dan Media (Edisi Terjemahan oleh Tjun Surjaman). Bandung: PT. Remaja Rosdakarya.

Papacharissi, Z. (2015). Affective Publics: Sentiment, Technology, and Politics. London: Oxford University Press. 
Pratama, A.B. (2016). Ada 800 Ribu situs Penyeber Hoaks di Indonesia. Diakses dari situs: http://www.cnnimdonesia.com/teknologi/2 0161229170130-185-182956/ada-800ribu-situs-penyebar-hoaks-di-indonesia/.

Robert, Bogdan \& Taylor, J. Steven. (1993). Metode Kualitatif: Dasar-Dasar Penelitian. Surabaya: Usaha Nasional.

Rudi, A. (2017). Kenapa "Hoaks" Mudah Tersebar di Indonesia? Diakses dari situs: http://megapolitan.kompas.com/read/2017 /02/08/21160841/kenapa.hoaks.mudah.ter sebar.di.indonesia.

Septanto, H. (2018). Pengaruh Hoaks dan Ujaran kebencian Sebuah Cyber Crime Dengan Tekhnologi sederhana di Kehidupan Sosial Masyarakat. Jurnal KalbiScientia Volume 5 No 2, Agustus 2018.

Stokes, J. (2006): How to Do Media and Cultural Studies. London: Sage.
Syahputra, I. (2017). Demokrasi Virtual dan Perang Siber di Media Sosial: Perspektif Netizen Indonesia. Jurnal ASPIKOM, Vol.3 No. 3, Juli 2017, hlm 457-475.

Tallis, B. (2016). Living in post-truth: Power/ Knowledge/ Responsibility. New Perspectives, 24(1), 7-18.

Tate, A. (2016). Facebook's False Reality: Why Fake Political News is on the Rise. New Statesman, September 9, 17. Accession number 117973830.

Tribunnews.com dengan judul Ini Beda Kampanye Hitam dan Kampanye Negatif. http://www.tribunnews.com/pemilu2014/2014/04/08/ini-beda-kampanyehitam-dan-kampanye-negatif.

Wimmer, R.D. and Dominick, J.R (2014). Mass Media Reseach and Introduction. Wadsworth: Cenggage learning. 